\title{
PENINGKATAN KEMAMPUAN MENGANALISIS UNSUR INTRINSIK CERPEN MELALUI METODE DISKUSI JENIS BUZZ GROUP PADA SISWA KELAS VIII A SMP DWIJENDRA GIANYAR TAHUN PELAJARAN 2011/2012
}

\author{
Ni Made Purnami Sari dan I Nyoman Suparsa \\ Program Studi Pendidikan Bahasa Indonesia \\ Fakultas Keguruan dan Ilmu Pendidikan \\ Universitas Mahasaraswati Denpasar
}

\begin{abstract}
This study is a classroom action research. It was conducted for the students at class VIII SMP DwijendraGianyar in the academic year 2011/2012. There were three cycles planned. There were 36 students. The object of the study was the improvement of ability in analyzing the intrinsic element of a short story through Buzz group discussion method. The results revealed that there was improvement in analyzing the intrinsic element of a short story after implementing Buzz group discussion method. It could be found from the mean score of the pretest was 4.2. It improved to 5.22 in the $1^{\text {st }}$ cycle, then up to 6.22 in the $2^{\text {nd }}$ cycle until achieving 7.38 in the $3^{\text {rd }}$ cycle. It means that the standard-passing score (SKBM) that is 7.00 was achieved.
\end{abstract}

Key words: analysis ability, intrinsic element, short story, Buzz group discussion method

\section{PENDAHULUAN}

Karya sastra dalam berbagai bentuknya sangat berperan aktif selama berabad-abad mengikuti gerak kebutuhan manusia. Oleh karena itu, pengajaran sastra di dunia sebagai cabang seni hampir sama dengan adanya manusia, karena ia diciptakan dan dinikmati manusia. Sastra telah menjadi bagian dari pengalaman hidup manusia, baik dari aspek penciptanya yang mengapresiasikan pengalaman bathinnya dari karya sastra maupun dari aspek pembaca untuk dapat menarik, menyerap nilai-nilai yang terkandung dalam karya sastra.

Pengajaran sastra dalam dunia pendidikan dimasukkan ke dalam pelajaran bahasa Indonesia. Sastra merupakan bagian dari kesenian yang memiliki unsur keindahan atau estetis yang perlu dilestarikan dan dikembangkan sehingga perkembangannya mengikuti zaman yang maju dan modern.

Dalam kehidupan sehari-hari seseorang tentu memerlukan bahasa sebagai alat perhubungan atau 
komunikasi dengan orang lain demikian pula di dunia pendidikan. Dunia pendidikan telah menyadari bahwa pengajaran bahasa merupakan kunci sukses bagi segala kegiatan pendidikan. Tujuan pengajaran bahasa dalam dunia pendidikan adalah untuk mendorong kemajuan individu dan sosial masyarakat. Melalui pengajaran bahasa di sekolah, para siswa juga didorong untuk menumbuhkan kemampuan berkomunikasi belajar hidup bermasyarakat dan menjadi warga negara yang berguna. Di samping itu, bahasa Indonesia merupakan satu-satunya bahasa kebudayaan dalam arti seluas- luasnya dan sedalam-dalamnya, sehingga setiap pendapat dirumuskan dan setiap perasaan dapat dilukiskan dalam bahasa, khususnya bahasa Indonesia.

Peningkatan mutu pengajaran sastra Indonesia memang tidak terlepas dari usaha untuk meningkatkan mutu apresiasi siswa terhadap sastra Indonesia. Untuk mencapai hal itu, maka dewasa ini sedang giat-giatnya dilakukan usaha meningkatkan apresiasi masyarakat terhadap karya sastra.

Untuk memperkenalkan karya sastra kepada generasi muda, berbagai usaha dilakukan oleh Pusat Pembinaan dan Pengembangan Bahasa agar masyarakat lebih mudah mengapresiasikan sebuah karya sastra. Mengapresiasikan karya sastra merupakan salah satu kegiatan yang banyak diminati masyarakat. Kegemaran mengapresiasikan sastra tidak hanya melanda kaum muda saja tetapi juga anak-anak sampai orang tua ikut menikmatinya. Hal itu merupakan suatu hal yang wajar karena melalui kegiatan mengapresiasikan karya sastra masyarakat khususnya para peminat sastra akan mengetahui nilai-nilai yang terkandung dalam karya sastra.

Kegiatan membaca dan mengapresiasikan karya sastra merupakan salah satu kehidupan manusia. Ketika pembaca mengapresiasikan salah satu judul cerpen atau cerita pendek, setelah pembaca melaksanakan kegiatan membaca terhadap keseluruhan cerpen itu, pembaca lebih lanjut menampilkan pertanyaan-pertanyaan, misalnya cara penokohannya, settingnya, perwatakan setiap tokoh dan pertanyaan tentang unsur intrinsik lain yang terdapat dalam cerpen itu, pembaca kembali membaca ulang sambil berusaha 
menganalisis setiap unsur yang telah ditetapkannya. Yang paling penting cara melukiskan kemampuan siswa kelas VIII dalam menggunakan bahasa Indonesia untuk memahami unsurunsur intrinsik salah satu hasil karya sastra. Hal ini menunjukkan, bahwakarya sastra (cerpen) membuat beberapa hal yang berguna bagi masyarakat. Dengan adanya langkahlangkah ini, maka perkembangan sastra Indonesia akan mengalami kemajuan yang pesat.

Berbicara tentang karya, maka sastra salah satuya adalah cerpen atau cerita pendek merupakan sebuah karya sastra yang menceritakan kehidupan manusia. Dalam cerpen banyak mengangkat tentang nilai-nilai kehidupan dalam masyarakat yang kemudian dikemas menjadi sebuah cerita yang menarik dan penuh konflik agar menjadi pusat perhatian untuk memancing pembaca. Karya sastra mengandung sesuatu yang amat berguna bagi manusia dapat memberikan kesantaian, membangkitkan daya kreasi dan memberikan keindahan, estetis semua karya sastra pada umumnya dan cerpen atau cerita pendek pada khususnya mempunyai struktur didalam karya sastra.

Berdasarkan hasil pengamatan terhadap proses belajar-mengajar di kelas VIII A SMP Dwijendra Gianyar penulis menemukan beberapa permasalahan yang ditimbulkan, baik oleh guru maupun siswa khususnya dalam menganalisis unsur intrinsik cerpen. Pada saat proses belajarmengajar berlangsung khususnya ketika siswa disuruh untuk menganalisis unsur intrinsik cerpen yang terdapat dalam cerpen, siswa mengalami kesulitan dalam menemukan unsur intrinsik tersebut, karena selama ini siswa hanya diberikan pengetahuan tentang teori pengertian dari tema, penokohan, amanat, latar dan juga sudut pandang, tetapi tidak dijelaskan cara menentukan unsur-unsur tersebut, selain itu siswa juga tidak terlalu serius membaca cerpen, dan kebanyakan siswa ngobrol dengan teman sebangkunya, bersenda gurau dengan temannya sambil lemparlemparan kertas tanpa memperhatikan apa yang diberitahu oleh guru. Kondisi belajar yang seperti ini dapat mengakibatkan hasil belajar yang diharapkan jauh dari nilai standar, dan 
siswa menganggap pelajaran menganalisis unsur intrinsik cerpen ini merpakan pelajaran yang membosankan, dan murid pun menjadi malas untuk mengikuti pelajaran ini. Hal ini disebabkan oleh, kurangnya kemampuan guru tersebut dalam melaksanakan pembelajaran inovatif untuk meningkatkan motivasi belajar siswa.

Mengacu pada paparan di atas, dapat diidentifikasi penyebab rendahnya kemampuan siswa kelas VIII A dalam menganalisis unsur intrinsik cerpen di SMP Dwijendra Gianyar, yaitu disebabkan oleh guru yang kurang mampu menerapkan metode pembelajaran yang inovatif untuk memotivasi siswa meningkatkan kreativitas dan aktivitas dalam menganalisis unsur intrinsik cerpen. Selama ini pembelajaran yang dilaksanakan cenderung menoton dan hanya menitikberatkan pada pengertian dan teori tanpa ada praktek langsung proses dalam memecahkan suatu permasalahan yang dihadapi.

Untuk itu dalam pembelajaran diperlukan metode yang sesuai dengan tingkat perkembangan siswa. Dengan demikian, pemilihan metode yang tepat dan efektif sangat diperlukan.
Sebagaimana pendapat Sudjana (1987:76), bahwa peranan metode mengajar sebagai alat untuk menciptakan proses belajar dan mengajar. Oleh karena itu, dalam penelitian ini peneliti menggunakan metode diskusi kelompok kecil atau metode buzz group. Tujuan utama metode diskusi jenis buzz group ini adalah untuk mengetahui sejauh mana keaktivan dan kemampuan guru, keterampilan kooperatif siswa, keterampilan guru dalam mengelola pembelajaran, dan hasil belajar siswa pada pokok bahasan perbandingan dan fungsi trigonometri dengan diterapkannya pembelajaran kooperatif menggunakan metode diskusi dengan teknik buzz group (kelompok aktif).

Metode diskusi jenis buzz group diaplikasikan dalam proses belajar mengajar untuk:

a. Mendorong siswa berpikir kritis;

b. Mendorong siswa mengekspresikan pendapatnya secara bebas;

c. Mendorong siswa menyumbangkan buah pikirannya untuk memecahkan masalah bersama; dan 
d. Mengambil satu alterntaif jawaban atau beberapa alternative jawaban untuk memecahkan masalah berdasarkan pertimbangan yang seksama.

Penulis memandang perlu mengadakan penelitian tentang "peningkatan kemampuan menganalisis unsur intrinsik cerpen pada tingkat SMP" karena mengingat betapa pentingnya pembaca cerpen mengetahui unsur - unsur intrinsik cerpen, maka dalam pembelajaran sastra disekolah, khususnya yang menyangkut tentang pengajaran cerpen, kegiatan menulis unsur usnsur intrinsik cerpen harus mendapat perhatian yang lebih dari guru Bahasa Indonesia.Berdasarkan pemaparan tersebut, maka permasalahan yang dibahas dalam penelitian ini adalah apakah metode diskusi jenis buzz group dapat meningkatkan kemampuan menganalisis unsur intrinsik cerpen pada siswa kelas VIII A SMP Dwijendra Gianyar Tahun Pelajaran 2011/2012?

\section{METODE PENELITIAN}

Jenis penelitian yang dilakukan adalah Penelitian Tindakan Kelas (PTK). PTK adalah suatu bentuk penelitian yang bersifat refleksif dengan melakukan tindakan-tindakan tertentu agar dapat memperbaiki dan meningkatkan praktek-praktek pembelajaran di kelas secara profesional. PTK ini dilakukan dalam beberapa siklus pada pembelajaran menganalisis unsur intrinsik cerpen di kelas VIII A SMP Dwijendra Gianyar Tahun Pelajaran 2011/2012 (Noviari,2010:25).

Subjek dalam penelitian ini adalah siswa kelas VIIIA SMP Dwijendra Gianyar Tahun Pelajaran 2011 / 2012 yang berjumlah 36 orang. Selanjutnya, objek penelitian ini adalah peningkatan kemampuan menganalisis unsur intrinsik cerpen melalui metode diskusi jenis buzz. group.

Setiap siklus dalam penelitian ini dilaksanakan berdasarkan hasil kolaborasi dan refleksi setelah satu tindakan dilaksanakan. Untuk mengetahui kemampuan awal siswa, maka dilaksanakan pra test. Pelaksanaan penelitian dengan menggunakan metode diskusi terdiri 
atas perencanaan (planning), tindakan (acting), pengamatan (observasi) dan refleksi (reflecting). Penelitian tindakan kelas ini rencananya akan dilakukan hingga siklus ke N. Adapun target menganlisis cerpen siswa kelas VIII A SMP Dwijendra Gianyar tahun ajaran 2011/2012 adalah 7,00. Nilai 7,00 merupakan nilai yang terdapat dalam SKBM (Standar Ketuntasan Belajar Minimum) di lingkungan SMP. Dalam perencanaannya, peneliti menggunakan (1) buku paket bahasa Indonesia, (2) mempersiapkan renacana pelaksanaan pembelajaran (RPP), (3) mempersiapkan sebuah cerpen, dan (4) tes akhir untuk siklus.

Kegiatan evaluasi diadakan pada akhir pertemuan siswa untuk mengetahui peningkatan kemampuan menganalisis unsur intrinsik cerpen melalui metode diskusi jenis buzz group. Pada proses pembelajaran, kegiatan pembelajaran berlangsung cukup baik, kegiatan pembelajaran berlangsung dalam kondisi yang aktif, efektif, dan menyenangkan.

Peningkatan kemampuan menganalisis unsur intrinsik cerpen melalui metode diskusi pada siklus I masih ada beberapa masalah yang ditemukan peneliti pada proses pembelajaran siklus I yang perlu dijadikan bahan refleksi untuk perbaikan siklus selanjutnya. Masalah yang muncul dalam pengambilan siklus I, siswa masih enggan untuk mengajukan pertanyaan-pertanyaan meskipun telah diberikan kesempatan. Hal ini terjadi karena siswa belum cermat dan cepat dalam menganalisis unsur intrinsik cerpen. Maka peneliti menganggap perlu melanjutkan pelaksanaan pembelajaran ke siklus II.

Analisis data tes secara kuantitatif dihitung dengan cara persentase melalui langkah-langkah: (1) merekap nilai yang diperoleh siswa, (2) menghitung nilai komunikatif dari seluruh aspek, (3) menghitung menentukan skor ideal yang diperoleh siswa, dan (4) menghitung nilai rata-rata dengan rumus :

$\mathrm{M}=\frac{\Sigma \mathrm{fx}}{\mathrm{N}}$

\section{PEMBAHASAN}

Berdasarkan hasil obervasi awal dan wawancara yang peneliti lakukan terhadap guru bahasa Indonesia kelas VIIIA SMP Dwijendra Gianyar diperoleh informasi bahwa kemampuan siswa di dalam memahami unsur intrinsik cerpen 
tergolong rendah. Hal ini terbukti dari hasil tes awal yang dilakukan peneliti untuk mengetahui kemampuan dasar yang dimiliki oleh siswa dengan nilai rata-rata kelas 4,2 dengan kategori kurang. Berdasarkan hasil yang dicapai pada tes awal, maka peneliti menganggap perlu dilaksanakan penelitian tindakan kelas. Hasil pretes ini belum mencapai SKBM (Standar Ketuntasan Belajar Minimum) yaitu 7,00. Oleh karena itu, peneliti harus melakukan upaya peningkatan kemampuan menganalisis unsur intrinsik cerpen melalui metode diskusi jenis buzz group.

Pelaksanaan pembelajaran siklus I dilaksanakan 1 kali pertemuan, yaitu pada hari Rabu, tanggal 8 Maret 2012. Dalam perencanaannya, peneliti menggunakan (1) buku paket bahasa Indonesia, (2) mempersiapkan rencana pelaksanaan pembelajaran (RPP), (3) mempersiapkan sebuah cerpen, dan (4) tes akhir untuk siklus I.

Tabel 01. Analisis Data Hasil Tes Kemampuan Menganalisis Unsur Intrinsik Cerpen Melalui Metode Diskusi Jenis Buzz Group pada Siklus I

\begin{tabular}{|c|c|c|c|c|c|c|c|}
\hline No & $\begin{array}{l}\text { Skor } \\
\text { Standar } \\
\text { (x) }\end{array}$ & $\begin{array}{c}\text { Frekue } \\
\text { nsi } \\
\text { (f) }\end{array}$ & $\begin{array}{c}\text { Jumlah } \\
\text { nilai } \\
\text { (fx) }\end{array}$ & $\begin{array}{l}\text { Persentase } \\
\quad(\%)\end{array}$ & Kategori & $\begin{array}{c}\text { Rentanga } \\
\text { n Skor }\end{array}$ & $\begin{array}{c}\text { Rata-rata } \\
\text { Nilai }\end{array}$ \\
\hline (1) & (2) & (3) & (4) & $(5)$ & (6) & (7) & (8) \\
\hline 1 & 10 & 0 & 0 & $0 \%$ & Istimewa & $52-60$ & 188 \\
\hline 2 & 9 & 0 & 0 & $0 \%$ & Baik sekali & $47-51$ & $=\overline{36}$ \\
\hline 3 & 8 & 0 & 0 & $0 \%$ & Baik & $42-46$ & $=188: 36$ \\
\hline 4 & 7 & 0 & 0 & $0 \%$ & Lebih dari & $37-41$ & $=5,22$ \\
\hline 5 & 6 & 10 & 60 & $27,7 \%$ & cukup & $32-38$ & (hampir \\
\hline 6 & 5 & 24 & 120 & $66,6 \%$ & Cukup & $27-31$ & cukup) \\
\hline 7 & 4 & 2 & 8 & $5,55 \%$ & $\begin{array}{l}\text { Hampir cukup } \\
\text { Kurang }\end{array}$ & $22-26$ & \\
\hline 8 & 3 & 0 & 0 & $0 \%$ & Kurang sekali & $17-21$ & \\
\hline 9 & 2 & 0 & 0 & $0 \%$ & Buruk & $12-16$ & \\
\hline \multirow[t]{2}{*}{10} & 1 & 0 & 0 & $0 \%$ & Buruk sekali & $7-11$ & \\
\hline & & 36 & 188 & $100 \%$ & & & \\
\hline
\end{tabular}

Berdasarkan tabel diatas, maka nilai rata-rata yang dicapai siswa adalah 5,22 dari 36 siswa dengan rincian, nilai 6 kategori cukup sebanyak 10 orang $(27,7 \%)$, nilai 5 kategori hampir cukup sebanyak 24 orang $(66,6 \%)$, nilai 4 kategori kurang sebanyak dua orang $(5,55 \%)$, sehingga 
kemampuan menganalisis unsur mempersiapkan cerpen, (5) guru intrinsik cerpen melalui pembelajaran membentuk kelompok diskusi, dan (6) buzz group dapat dikelompokkan menyusun tes hasil hasil belajar dan dalam kategori hampir cukup, ketentuan belum mencapai target maka perlu dilanjutkan ke siklus $\mathrm{N}$.

Pelaksanaan pembelajaran siklus II dilaksanakan pada tanggal 9 Maret 2012. Dalam perencanaannya, peneliti menggunakan: (1) buku paket bahasa Indonesia SMP Kelas VIII, (2) menyiapkan bahan pelajaran bahasa Indonesia, (3) menyusun rencana siklus II. Pada siklus II peneliti membimbing siswa untuk berlatih menganalisis unsur intrinsik cerpen melalui metode diskusi jenis buzz group sehingga siswa terbiasa untuk melakukan seperti ini, maka siswa akan mengalami kemajuan dan keberanian untuk mengajukan pertanyaan apabila siswa belum mengerti.

pelaksanaan pemebelajaran (RPP), (4)

Tabel 02. Analisis Data Hasil Tes Kemampuan Menganalisis Unsur Intrinsik Cerpen melalui Metode Diskusi Jenis Buzz Group pada Siklus II

\begin{tabular}{|c|c|c|c|c|c|c|c|}
\hline No & $\begin{array}{l}\text { Skor } \\
\text { Stand } \\
\text { ar } \\
(\mathrm{x}) \\
\end{array}$ & $\begin{array}{l}\text { Frekue } \\
\text { nsi } \\
\text { (f) }\end{array}$ & $\begin{array}{l}\text { Jumlah } \\
\text { nilai } \\
\text { (fx) }\end{array}$ & $\begin{array}{c}\text { Persenta } \\
\text { se } \\
(\%)\end{array}$ & Kategori & $\begin{array}{c}\text { Rentangan } \\
\text { Skor }\end{array}$ & $\begin{array}{c}\text { Rata-rata } \\
\text { Nilai }\end{array}$ \\
\hline$(1)$ & (2) & (3) & (4) & (5) & (6) & (7) & (8) \\
\hline 1 & 10 & 0 & 0 & $0 \%$ & Istimewa & $52-60$ & 224 \\
\hline 2 & 9 & 0 & 0 & $0 \%$ & Baik sekali & $47-51$ & $=\overline{36}$ \\
\hline 3 & 8 & 0 & 0 & $0 \%$ & Baik & $42-46$ & $=6.22$ \\
\hline 4 & 7 & 11 & 77 & $30,5 \%$ & Lebih dari & $37-41$ & (cukup) \\
\hline 5 & 6 & 22 & 132 & $61,1 \%$ & cukup & $32-38$ & \\
\hline 6 & 5 & 3 & 15 & $8,3 \%$ & Cukup & $27-31$ & \\
\hline 7 & 4 & 0 & 0 & $0 \%$ & Hampir & $22-26$ & \\
\hline 8 & 3 & 0 & 0 & $0 \%$ & cukup & $17-21$ & \\
\hline 9 & 2 & 0 & 0 & $0 \%$ & Kurang & $12-16$ & \\
\hline \multirow[t]{2}{*}{10} & 1 & 0 & 0 & $0 \%$ & $\begin{array}{l}\text { Kurang sekali } \\
\text { Buruk } \\
\text { Buruk sekali }\end{array}$ & $7-11$ & \\
\hline & & 36 & 224 & $100 \%$ & & & \\
\hline
\end{tabular}

Pembelajaran cerpen pada siklus II dapat diketahui bahwa rata-rata skor dari 36 siswa adalah 6,22 dengan rincian nilai 7 kategori lebih dari cukup sebanyak 11 orang (30,5\%), nilai 6 kategori cukup sebanyak 22 orang $(61,1 \%)$, nilai 5 kategori hampir cukup sebanyak 3 orang $(8,3 \%)$, 
sehingga kemampuan menganalisis cerpen melalui metode diskusi dapat dikelompokkan ke dalam kategori cukup, maka ketentuan belum mencapai target maka perlu dilanjutkan ke siklus III. Pelaksanaan pembelajaran siklus III dilaksanakan pada tanggal 14 Maret 2012. Dalam perencanaannya, peneliti menggunakan (1) Buku Cakap Berbahasa Indonesia SMP Kelas VIII, (2) menyiapkan bahan pembelajaran bahasa Indonesia, (3) menyiapkan rencana pelaksanaan pembelajaran (RPP), (4) membentuk kelompok diskusi, dan (5) membuat rangkuman. Pada tahap ini peneliti melaksanakan proses pembelajaran sesuai dengan rencana pelaksanaan pembelajaran. Kesulitan-kesulitan dalam tes awal, siklus I dan siklus II akan diperbaiki pada siklus III ini, dengan jalan peneliti memberikan pelatihan pemahaman mengenai unsur-unsur intrinsik cerpen secara lebih mendalam dan lebih teliti sehingga diharapkan ada peningkatan dan pemahaman yang nantinya semua siswa mendapat predikat baik. Siklus III ini merupakan tindakan terakhir yang diberikan karena peneliti sudah berlangsung dua kali yaitu siklus I dan II.

Tabel 03. Analisis Data Hasil Tes Kemampuan Menganalisis Unsur Intrinsik Cerpen Melalui Metode Diskusi Jenis Buzz Group pada Siklus III.

\begin{tabular}{|c|c|c|c|c|c|c|c|}
\hline No & $\begin{array}{c}\text { Skor } \\
\text { Standar } \\
\text { (x) } \\
\end{array}$ & $\begin{array}{c}\text { Frekuens } \\
\text { i } \\
\text { (f) }\end{array}$ & \begin{tabular}{|c|} 
Jumlah \\
nilai \\
(fx) \\
\end{tabular} & $\begin{array}{c}\text { Persentas } \\
\mathrm{e} \\
(\%) \\
\end{array}$ & Kategori & $\begin{array}{c}\text { Rentanga } \\
\text { n Skor }\end{array}$ & $\begin{array}{c}\text { Rata- } \\
\text { rata } \\
\text { Nilai } \\
\end{array}$ \\
\hline (1) & (2) & (3) & (4) & (5) & (6) & (7) & (8) \\
\hline 1 & 10 & 0 & 0 & $0 \%$ & Istimewa & $52-60$ & $=266: 36$ \\
\hline 2 & 9 & 0 & 0 & $0 \%$ & Baik sekali & $47-51$ & $=7,38$ \\
\hline 3 & 8 & 14 & 112 & $38,88 \%$ & Baik & $42-46$ & (lebih \\
\hline 4 & 7 & 22 & 154 & $61,1 \%$ & Lebih dari & $37-41$ & daricuku \\
\hline 5 & 6 & 0 & 0 & $0 \%$ & cukup & $32-38$ & p) \\
\hline 6 & 5 & 0 & 0 & $0 \%$ & Cukup & $27-31$ & \\
\hline 7 & 4 & 0 & 0 & $0 \%$ & Hampir & $22-26$ & \\
\hline 8 & 3 & 0 & 0 & $0 \%$ & cukup & $17-21$ & \\
\hline 9 & 2 & 0 & 0 & $0 \%$ & Kurang & $12-16$ & \\
\hline 10 & 1 & 0 & 0 & $0 \%$ & $\begin{array}{l}\text { Kurang sekali } \\
\text { Buruk } \\
\text { Buruk sekali }\end{array}$ & $7-11$ & \\
\hline & & 36 & 266 & $100 \%$ & & & \\
\hline
\end{tabular}



Berdasarkan tabel diatas, maka nilai kemampuan siswa dalam pembelajaran cerpen pada tes siklus III dapat diketahui bahwa nilai rata-rata dari 36 siswa adalah 7,38 dengan rincian, nilai 8 kategori baik sebanyak 14 siswa $(38,88 \%)$, nilai 7 kategori lebih dari cukup sebanyak $22(61,1 \%)$, sehingga kemampuan menganalisis cerpen melalui metode diskusi jenis buzz group pada siklus III dapat dikelompokkan lebih dari cukup sehingga penelitian tindakan kelas yang berjudul “ Peningkatan Kemampuan Menganalisis Unsur
Intrinsik Cerpen Melalui Metode Diskusi Jenis Buzz Group pada siswa kelas VIII A SMP Dwijendra Gianyar sudah memenuhi standar ketuntasan belajar mengajar yaitu 7,00 dan sudah tuntas berakhir pada siklus III.

Berdasarkan hasil yang diperoleh siswa pada pertemuan awal, secara umum pembelajaran menganalisis unsur intrinsik cerpen melalui metode diskusi jeniz buzz group pada siswa kelas VIIIA SMP Dwijendra Gianyar dari pretes hingga siklus III disajikan pada Tabel berikut ini.

Tabel 04. Rekapitulasi Hasil Tes Siklus I, Siklus II dan Siklus III Peningkatan Kemampuan Menganalisis Unsur Instrinsik Cerpen Melalui Metode Diskusi Jenis Buzz Group Siswa Kelas VIIIA SMP Dwijendra Gianyar

\begin{tabular}{|l|l|c|c|c|c|}
\hline No & Nama Siswa & Tes Awal & Siklus I & Siklus II & Siklus III \\
\hline$(1)$ & \multicolumn{1}{|c|}{$(2)$} & $(3)$ & $(4)$ & $(5)$ & $(6)$ \\
\hline 1 & A.A Ari Tresna Nanda & 4 & 5 & 5 & 7 \\
\hline 2 & I kadek Adi Dwi Mahendra & 4 & 5 & 6 & 7 \\
\hline 3 & I Kadek Agus Mardika & 4 & 5 & 6 & 8 \\
\hline 4 & Pande Nyoman Adi Putra & 4 & 5 & 6 & 7 \\
\hline 5 & I Ketut Adi Surya Kencana & 4 & 5 & 6 & 7 \\
\hline 6 & Dw. Ayu Ari Candra Dewi & 4 & 5 & 7 & 7 \\
\hline 7 & I Kadek Ari Wiguna Saputra & 4 & 5 & 6 & 8 \\
\hline 8 & Kadek Ayu Dwi Lestari & 4 & 5 & 6 & 7 \\
\hline 9 & I Kadek Budi Anggara & 4 & 5 & 6 & 7 \\
\hline 10 & I Gusti Bagus Tirta Talagawana & 4 & 5 & 6 & 7 \\
\hline 11 & Desak Made Desi Tresnawati & 4 & 5 & 6 & 8 \\
\hline 12 & I Putu Gede Eka Suryawan & 4 & 5 & 6 & 7 \\
\hline 13 & I wyn. Eko Purnomo & 3 & 5 & 6 & 7 \\
\hline 14 & Ni Made Indah Laraswati & 4 & 5 & 6 & 7 \\
\hline 15 & Gusti Ngurah Hery Sanjaya & 4 & 5 & 6 & 7 \\
\hline 16 & Dw. Ayu Komang Maharani & 3 & 4 & 5 & 7 \\
\hline 17 & Kadek Mahendra Ambara & 3 & 4 & 5 & 7 \\
\hline 18 & Ni Putu Meiliana Wulansari & 5 & 6 & 7 & 8 \\
\hline 19 & Metalia Teja & 5 & 6 & 7 & 8 \\
\hline 20 & I Komang Mahardika & 5 & 6 & 7 & 8 \\
\hline 21 & Gusti Ngurah Parimana & 4 & 5 & 6 & 7 \\
\hline 22 & Dwi Putra Indrayana Aror & 6 & 7 & 8 \\
\hline 23 & Luh Kadek Rahayu Pratiwi & & & 7 \\
\hline & & 4 & 6 & 7 & 7 \\
\hline
\end{tabular}




\begin{tabular}{|l|l|c|c|c|c|}
\hline 24 & Ni Wayan Rupianti & 5 & 6 & 7 & 8 \\
\hline 25 & Putu Sukma Asih & 5 & 6 & 7 & 8 \\
\hline 26 & Dewa Ayu Septia Ayu & 5 & 5 & 6 & 7 \\
\hline 27 & Ni Wayan Septiari Musdayanti & 4 & 5 & 6 & 7 \\
\hline 28 & Dewa Made Sukasila & 4 & 5 & 6 & 7 \\
\hline 29 & Gusti Ayu Putu Santiani & 4 & 6 & 7 & 8 \\
\hline 30 & Ni Kadek Widiari & 5 & 6 & 7 & 8 \\
\hline 31 & Ni Gusti Ayu Widiari & 4 & 5 & 6 & 7 \\
\hline 32 & Ni Komang Tri Nugraheni & 4 & 5 & 6 & 7 \\
\hline 33 & A.A Gede Tarunan Widjaya & 4 & 5 & 6 & 7 \\
\hline 34 & I Wayan Yuri Yanantara & 4 & 5 & 6 & 7 \\
\hline 35 & Sang Ayu Putu Juliana Prisma & 5 & 6 & 7 & 8 \\
\hline 36 & Pande Komang Eukaristia & 4 & 5 & 6 & 8 \\
\hline & Jumlah & 150 & 188 & 224 & 266 \\
\hline & Rata-rata & 4,2 & 5,22 & 6,22 & 7,38 \\
\hline
\end{tabular}

Dengan perbandingan di atas, dikatakan bahwa tingkat kemampuan menganalisis unsur intrinsik cerpen mealui metode diskusi jenis buzz group mengalami peingkatan yang baik. Hal ini dapat dilihat dari perbandingan nilai rata-rata yang diperoleh pada siklus I,II,dan III. Adapun perinciannya sebagai berikut.

1. Pada tes awal peningkatan kemampuan menganalisis unsur intrinsik cerpen dari 36 siswa memperoleh nilai rata-rata 4,2 yang dikelompokkan dalam kategori kurang.

2. Pada siklus I peningkatan kemampuan menganalisis unsur intrinsik cerpen melalui metode diskusi dari 36 siswa memperoleh nilai rata-rata 5,22 yang dikelompokkan dalamkategori hampir cukup
3. Pada siklus II peningkatan kemampuan menganalisis unsur intrinsik cerpen melalui metode diskusi jenis buzz group dari 36 siswa memperoleh nilai rata-rata 6,22 yang dikelompokkan kategori cukup.

4. Pada siklus III peningkatan kemampuan menganalisis unsur intrinsik cerpen melalui metode diskusi dari 36 siswa memperoleh nilai rata-rata $7,38 \quad$ yang dikelompokkan dalam kategori baik.

Peningkatan nilai rata-rata dari siklus I ke siklus II dan dari siklus II ke siklus III berarti pula kesalahan bahasa yang dibuat siswa juga semakin berkurang. Dengan sedemikian berkurangnya kesalahan bahasa yang dibuat siswa berarti pula kemampuan siswa menganalisis unsur intrinsik cerpen semakin meningkat. 
Selain itu, hasil yang diperoleh dalam proses penelitian ini secara keseluruhan, dari tes awal, siklus I, siklus II, dan siklus III terhadap cerpen sangat baik diterapkan dalam pembelajaran khususnya untuk meningkatkan kemampuan menganalisis unsur-unsur intrinsik cerpen dengan langkah-langkah yang tepat dapat meningkatkan kemampuan siswa dengan baik.

\section{PENUTUP}

\section{Simpulan}

Berdasarkan hasil penelitian yang telah dipaparkan di atas, makadapat ditarik simpulan, bahwa metode diskusi jenis buzz group dapat meningkatkan kemampuan menganalisis unsur intrinsik cerpen pada siswa kelas VIII A SMP Dwijendra Gianyar Tahun Pelajaran 2011/2012, dengan bukti-bukti yaitu pada tindakan pra siklus (tahap awal) tes menganalisis unsur intrinsik cerpen siswa hanya mencapai nilai rata-rata 4,2. Hal ini dibuktikan saat tes awal berlangsung, dapat diketahui bahwa nilai rata-rata sebesar 4,2 dari 36 siswa. Dari hasil tes awal tersebut dapat dilihat bahwa kemampuan siswa di dalam memahami isi bacaan masih sangat kurang.

Pada siklus I ini nilai rata-rata siswa mengalami peningkatan yaitu 5,22 tetapi masih di bawah standar yang ditentukan. Oleh karena itu, dianggap masih di bawah standar, maka diperlukan adanya tindakan siklus II. Pada siklus II ini, nilai ratarata kemampuan siswa mengalami peningkatan lagi yaitu 6,22. Pada siklus II ini nilai rata-rata siswa juga masih dikategorikan di bawah standar, maka diperlukan lagi ada tindakan siklus III. Pada siklus III nilai rata-rata siswa mengalami peningkatan lagi yakni mencapai 7,38. Dengan demikian, maka tindakan penelitian dihentikan pada siklus III, karena target yang ditentukan sudah tercapa dengan kategori lebih dari cukup.

\section{Saran}

Pelaksanaan penelitian yang dilaksanakan pada siswa kelas VIII A SMP Dwijendra Gianyar tahun pelajaran 2011/2012 ini ada beberapa saran yang dapat dipergunakan untuk mengefektifkan pembelajaran bahasa dan sas Indonesia pada umumnya, dan pembelajaran menganalisis unsur intrinsik cerpen pada khususnya, yaitu: 
1. Guru hendaknya memberikan rangsangan terhadap minat baca siswa khususnya karya sastra, sehingga pengetahuan siswa tentang sastra bertambah;

2. Bagi guru-guru dalam melaksanakan proses pembelajaran khususnya bahasa Indonesia khususnya menganalisis unsur intrinsik cerpen, agar menciptakan suasana yang kondusif sehingga dapat mendukung keberhasilan siswa; dan

3. Perpustakaan sekolah hendaknya lebih dilengkapi dengan sarana buku yang memadai, karena perlengkapan ini akan merangsang minat baca siswa di perpustakaan.

Demikian saran yang dapat penulis sampaikan. Semoga saran ini dapat bermanfaat dalam pengajaran bahasa dan sastra Indonesia khususnya dalam memahami unsur-unsur karya sastra.

\section{DAFTAR PUSTAKA}

Arifin, E Zainal. (1987). Bahasa Indonesia SMP. Jakarta: Erlangga.

Arikunto, Suharsini, dkk. (2008). Penelitian tindakan kelas. Jakarta: Bumi Aksara.

Depertemen Pendidikan dan Kebudayaan. (1996). Pedoman umum ejaan Bahasa Indonesia yang disempurnakan. Jakarta: Balai Pustaka.

Hadi, Sutrisno. (1971). Metode reasearch. Yogyakarta: Fakultas Psikologi Universitas Gajah Mada.

Netra,I.B. (1974). Metodelogi penelitian. Singaraja: Biro penelitian dan Penerbitan FKIP Unud. 